\title{
The Fall of the Iron Curtain: 30 Years On
}

Autumn 2019 marks 30 years since the fall of the Berlin Wall. The end of one-party Communist rule across Central and Eastern Europe, followed by the collapse of the Soviet Union in 1991, began a new phase in Europe's - and to some extent the world's - history. German unification became a reality, as did European unification through the enlargement of the European Union.

The economic dimension of this politically driven process has proven to be much harder. For many, the question has always been to what extent and at what speed the East could fulfil its great aspiration to catch up with the West and attain the same level of development. After 30 years, it seems that neither the German nor the broader European context has allowed for overcoming the fundamental asymmetries. Economic growth in Central and Eastern Europe since the EU enlargement has been convincingly higher than the EU average, but in most cases this only offset the losses of the early 1990s, while internal inequality and territorial imbalances became greater.

The Eastern question is often framed in a political and cultural context without sufficient attention to economic and social aspects. The good news is that there is economic convergence between the East and the West. However, those who believe that problems in the East will slowly be resolved by higher GDP growth need to look beyond economic figures to the gaps in health indicators and the extraordinary population decline experienced in eastern EU Member States.

Economic convergence seems to be coupled with divergence regarding political values and social models. Therefore, the EU not only needs to make efforts to ensure that there is sustained economic growth in the East but also to recouple that growth with convergence in terms of political and social policy standards. In the long run, such recoupling is the real solution to the problem of social dumping, a central focus of legislative activity in the past decade.

From a Western perspective, the pervasive East-West divide is often exposed through controversies around labour mobility. Upholding the right to free movement and ensuring equal treatment for mobile workers remains a pivotal issue for the EU. A key question in this context today is how the periphery regions (mainly in the East) can rebuild human capital, after years of constant emigration.

The fall of the Berlin Wall is not the only 30th anniversary that deserves attention. Coincidentally, 1989 was also the year the so-called Washington Consensus was born. The doctrine attempted to layout a sound and undisputed policy package for emerging economies. By agreeing on the 'ten commandments', the Washington-based institutions - the International Monetary Fund (IMF) and the World Bank - managed to iron out their disagreements.

The Washington Consensus quickly became synonymous not only with economic globalisation but also with reckless deregulation, liberalisation and privatisation. Perhaps unintentionally, the Washington Consensus indeed contributed to a simplistic approach to economic policy, as a kind of economic equivalent of Francis Fukuyama's book The End of History?, published originally as an essay also in 1989. This often resulted in discrediting the IMF and the World Bank and damaging multilateralism. Efforts have been made, however, to integrate tackling inequality and climate change into the goals of multilateral institutions. This could and should lead to a global governance structure capable of ensuring economic, social, environmental and institutional sustainability.

The old Washington Consensus is clearly an 'ex-parrot', but we cannot yet speak about a new consensus, not even within the EU. After the crises of the global financial system and the Economic and Monetary Union (EMU), there is probably agreement that we cannot go back to the original model that emerged 30 years ago (eminently formulated by the Delors Committee's report in April 1989), but there are still major disagreements about the shape and size of the EMU 2.0. Scrapping 
the Schwarze Nulls of this world would probably be popular, but creating new fiscal rules to replace them is more difficult. Industrial policy is gaining traction, but it is hard to identify a concrete practice that would deliver it in a way that also preserves competition standards.

The twilight of a globalist era is probably most apparent in international trade. We are all set to lose here; and those who think the gamble is worth it consider trade conflicts a tool for achieving other goals. But again, when we see Donald Trump, Boris Johnson and others destroying existing multilateral frameworks of trade and investment, the answer cannot just be a defence of the status quo ante. New mechanisms are needed that foster not only convergence and sustainability but also, in the European context, solidarity.

In order to appreciate this last point we need to highlight a third important anniversary from the year 1989: the adoption of the Community Charter of the Fundamental Social Rights of Workers on 9 December in Strasbourg. Former European Commission President Jacques Delors knew that a single market without a social dimension would not gain public support. Some might have thought he was just sugar-coating trade liberalisation. However, Delors ensured that a cycle of social policy legislation would be launched, devoted a large share of the EU budget to Cohesion Policy and established the EU-level dialogue between employers and trade unions.

Those who believe that the 1989 document is just a souvenir must look at one of the emblematic products of the outgoing Juncker Commission: the European Pillar of Social Rights can be interpreted as reminiscent of the 1989 Social Charter, but with important references to 21st century questions. Because it was adopted as a collection of 20 non-binding principles, it is up to the new Commission entering office under the leadership of Ursula von der Leyen to consider potential concrete measures that could render it a more effective component of the EU architecture.

The house Jacques Delors built was later supplemented by the Lisbon Strategy in the year 2000 and by its successor strategy called Europe 2020 in the year 2010. To some extent, the Lisbon Strategy, and the long-term coordination approach it introduced, was meant to be the progressive answer to the narrow focus of the Maastricht EMU model on nominal convergence, i.e. low deficits and low inflation, and its indifference to the real economic and social costs. Indeed, the late 1990s produced the European Employment Strategy together with the endeavour to reconcile the Single Market and single currency with the European Social Model. Now is the time to reflect on the strengths and limitations of this approach and improve it if possible.

For the past five years, the Europe 2020 strategy has been kept in the shadows. But the time is coming for an assessment of the progress being made towards achieving the goals of the strategy that were quantified and defined as numerical targets. Some will say the EU should refrain altogether from such visions and developmental efforts. However, the problem with Europe 2020 was not that it wanted to address long-term structural questions, but that there was no consistency between the long- and short-term foci and tools. While outlining the avenues of smart, sustainable and inclusive growth, economic governance failed to consider the risks posed by the lack of adequate safety nets in the minimalist monetary union.

The incompleteness of the EMU is an existential question for the single currency, and arguably for the EU. Its minimalist model leaves adjustment up to internal devaluation in times of crisis. This is suboptimal for growth because it represents a direct threat to the collective bargaining systems and welfare states of the euro area periphery. Failure to minimise this danger leaves the system too fragile, even if the type of crisis that hit Europe in 2008/09 is unlikely to return.

László Andor, Foundation for European Progressive Studies, Brussels, Belgium.
Five years ago, the newly established Juncker Commission called itself the 'Commission of Last Chance'. But after the European economy recovered from the recession, vital EMU reforms remained the subject of mere reflection. The heavy lifting has been left to the next European Commission of Ursula von der Leyen. 